\title{
PENGGUNAAN METODE ROLE PLAYING UNTUK MENINGKATKAN HASIL BELAJAR ETIKA PUBLIK
}

\author{
Tarmujianto \\ Widyaiswara BPSDM Provinsi DKI Jakarta \\ Email: tarmujiant@yahoo.co.id
}

\begin{abstract}
Abstrak
Penelitian ini bertujuan untuk mengetahui dan menganalisis tentang pengaruh penggunaan metode pembelajaran role playing terhadap hasil belajar peserta latsar CPNS tahun 2019 pada mata pelatihan Etika Publik. Penelitian ini menggunakan metode penelitian eksplanasi, sedangkan jenis penelitian yang digunakan adalah penelitian eksperimen. Desain yang digunakan dalam penelitian ini adalah Nonequivalent Control Group Design. Desain ini hampir sama dengan pretest-postest control group design, hanya pada desain ini kelompok eksperimen maupun kelompok kontrol tidak dipilih secara random. Hasil penelitian menunjukkan bahwa penggunaan metode pembelajaran role playing dinilai cukup efektif untuk meningkatkan hasil belajar Etika Publik. Sementara kelas yang menggunakan metode pembelajaran konvensional ceramah dapat dikatakan kurang efektif untuk meningkatkan hasil belajar mata pelatihan Etika Publik. Penggunaan metode pembelajaran role playing memberikan pengaruh sebesar 47,8\% terhadap hasil belajar mata pelatihan Etika Publik, sedangkan sisanya sebesar $52,2 \%$ dipengaruhi oleh faktor-faktor selain penggunaan metode pembelajaran role playing.
\end{abstract}

Kata Kunci : Etika Publik, Pelatihan, Role Playing

\begin{abstract}
This study aims at determining and analyzing the effect of role-playing learning methods on the learning outcomes of CPNS training participants in 2019 in the Public Ethics course. This study used explanatory research methods, while the type of research used was experimental research. The design used in this research was the Nonequivalent Control Group Design. This design closely similar to the pretest-posttest control group design, however, in this design the experimental group and the control group were not randomly selected. The results showed that the use of role-playing learning methods was considered effective enough to improve the learning outcomes of Public Ethics. While classes that used the conventional lecture learning method can be said to be less effective in improving learning outcomes for the Public Ethics training course. The use of role-playing learning methods had an effect of $47.8 \%$ on the learning outcomes of the Public Ethics training course, while the remaining $52.2 \%$ was influenced by factors other than the use of role-playing learning methods.
\end{abstract}

Key Words : Public Ethics, Training, Role Playing

\section{PENDAHULUAN}

Aparatur Sipil Negara atau yang lebih dikenal ASN adalah profesi bagi pegawai negeri sipil dan pegawai pemerintah dengan perjanjian kerja yang bekerja pada instansi pemerintah [1]. Ketika seseorang memilih karir hidupnya sebagai Aparatur Sipil Negara, maka sejatinya ia telah menjadi bagian dari "kekuasaan" yang tindak tanduknya berimplikasi terhadap kepentingan masyarakat luas. Masyarakat memiliki tuntutan dan harapan yang tinggi kepada aparat pemerintah. Untuk dapat membentuk sosok ASN profesional sebagaimana yang diharapkan, maka perlu dilakukan kegiatan pembinaan melalui jalur pelatihan dasar. Seiring dengan telah ditetapkannya [1] tentang Aparatur Sipil Negara (ASN) pada Pasal 63 ayat (3) dan ayat (4), mengamanatkan kepada Instansi/Pemerintah untuk wajib memberikan Pendidikan dan Pelatihan Dasar (Latsar) yang Terintegrasi bagi Calon Pegawai Negeri Sipil (CPNS) selama 1 (satu) tahun masa percobaan, dengan mengutamakan penguatan nilainilai dan pembangunan karakter dalam mencetak ASN. Peraturan [2] yang ditetapkan tanggal 12 Desember 2018 tentang Pelatihan Dasar Calon Pegawai 
Negeri Sipil (Latsar CPNS), maka Penyelenggaraan kegiatan yang sebelumnya dikenal dengan nama Pendidikan dan Pelatihan (DIKLAT) Prajabatan, diganti dengan nomenklatur baru yakni Pelatihan Dasar Kader CPNS, sebagai salah satu kegiatan pelatihan yang strategis pasca ditetapkannya UU ASN dalam rangka pembentukan kemampuan bersikap dan bertindak profesional yang berlandaskan pada nilai-nilai dasar yang meliputi: materi Akuntabilitas, Nasionalisme, Etika Publik, Komitmen Mutu, dan Anti Korupsi atau ANEKA, serta disinkronkan dengan kedudukan dan peran PNS dalam NKRI yang meliputi: materi Manajemen ASN, Whole of Government dan Pelayanan Publik.

Mata Pelatihan Etika Publik sebagai salah satu nilai dasar dalam pembentukan sikap seorang ASN ini, memberikan kesempatan pembentukan nilai-nilai dasar etika publik kepada peserta pelatihan melalui penyampaian materi kode etik dan perilaku pejabat publik, bentuk-bentuk kode etik dan implikasinya, dan materi penerapan kode etik PNS. Setelah memperoleh materi ini, peserta diharapkan mampu untuk mengaktualisasikan atau mempraktikkan nilai-nilai dasar etika publik dalam menjalankan tugas dan jabatannya.

Masalah-masalah pembelajaran etika publik yang sering ditemukan di antaranya adalah pembelajaran di kelas hanya mentransfer pengetahuan dalam satu arah, yakni dari widyaiswara kepada peserta pelatihan. Dalam hal ini, fakta, konsep, dan tuntutan etika lebih banyak disampaikan melalui ceramah atau tanya jawab. Hal itulah yang menyebabkan peserta latsar bersifat pasif selama proses pembelajaran di kelas. Penerapan metode pembelajaran dalam proses kediklatan harus mampu menyesuaikan dengan materi yang akan di sajikan kepada peserta serta tujuan-tujuan yang akan dicapai. Metode yang digunakan hendaknya menekankan bahwa peserta pelatihanlah yang membangun proses pembelajaran. Apabila peserta pelatihan telah memiliki keinginan untuk mengetahui, mengamati, mempelajari dengan serius, maka hubungan antara widyaiswara dan peserta akan mengalami sinergitas yang pada gilirannya akan mewujudkan hasil akhir (out put) menjadi lebih baik.

Calon Pegawai Negeri Sipil di lingkungan Pemerintah Provinsi DKI Jakarta yang merupakan episentrum bagi kota-kota lain di Indonesia, diharapkan memiliki nilai hasil belajar pelatihan dasar yang sangat memuaskan. Namun berdasarkan data yang kami peroleh dari penyelenggara, bahwa hasil evaluasi untuk peserta Latsar CPNS Golongan III yang diselenggarakan oleh BPSDM Provinsi DKI Jakarta, pada tahun 2019 lalu, hasilnya secara umum nilainya baru pada taraf memuaskan, berdasar Peraturan [2] Bab V Pasal 19 ayat 1 yang menyebutkan tentang kriteria penilaian hasil kelulusan peserta Latsar CPNS sebagai berikut:

\section{Tabel 1. Kualifikasi Kelulusan}

\begin{tabular}{lc}
\hline Kriteria & Skor \\
\hline Sangat Memuaskan & $90,01-100$ \\
Memuaskan & $80,01-90,0$ \\
Cukup Memuaskan & $70,01-80,0$ \\
Kurang Memuaskan & $60,01-70,0$ \\
Tidak Memuaskan & $\leq 60$ \\
\hline
\end{tabular}

Oleh karena itu, diperlukan suatu tindakan untuk memperbaiki masalah-masalah tersebut, sehingga hasil belajar peserta menjadi lebih berkualitas serta memotivasi peserta untuk berpikir kreatif dan bersikap aktif dalam belajar. Dari beberapa solusi yang ada untuk pemecahan masalah tersebut, maka diambil suatu tindakan dengan menerapkan metode role playing. Metode Role Playing atau Bermain Peran pada hakikatnya merupakan sebuah metode yang 'menghadirkan' peran-peran 
dalam dunia nyata ke dalam suatu 'pertunjukan peran' di dalam kelas atau pertemuan [3]. Metode roleplay berfungsi sebagai media melatih hubungan antar pribadi (intrepersonal relationship) untuk menciptakan suasana spontanitas dan kreativitas [4]. Metode role-playing berperan dalam mengaktifkan semua peserta dalam kelompok belajar dan membantu mereka mengasah keterampilan interpersonal menjadi lebih baik [5]. Hasil penelitian menyatakan bahwa model pembelajaran Role Playing Berorientasi Tri Kaya Parisudha berpengaruh positif terhadap hasil belajar IPS siswa [6]. Hasil penelitian lain menyatakan bahwa penggunaan metode Role Playing dan media Orkas (Organ Koran Bekas) dapat meningkatkan prestasi belajar siswa mata pelajaran Biologi [7]. Penelitian selanjutnya menyatakan bahwa model pembelajaran kooperatif tipe Role Playing terbukti efektif dalam meningkatkan hasil belajar siswa [8]. Hasil belajar tersebut terdiri dari informasi verbal, kemampuan intelektual, psikomotorik, sikap atau afektif dan siasat kognitif. Hasil belajar merupakan suatu hasil dari sebuah interaksi dalam kegiatan belajar dan mengajar [9].

Penelitian ini memiliki tujuan untuk mengetahui dan menganalisis tentang penerapan metode role playing serta pengaruhnya terhadap hasil belajar peserta latsar pada materi Etika Publik. Manfaat dari penelitian ini dapat menjadi bahan informasi dan rekomendasi bagi BPSDM dalam upaya peningkatan kualitas dalam menyelenggarakan kegiatan pendidikan dan pelatihan melalui penerapan metode pembelajaran yang efektif oleh Widyaiswara, serta untuk mempermudah penyampaian suatu materi yang memerlukan aktualisasi dan kecakapan sosial dalam pencapaian tujuannya. Hipotesis yang diajukan dalam penelitian ini adalah ada pengaruh penggunaan metode role playing terhadap hasil belajar Etika Publik.

\section{METODE}

Penelitian ini menggunakan metode penelitian eksplanasi, sedangkan jenis penelitian yang digunakan adalah penelitian eksperimen (experimental research), merupakan pendekatan penelitian kuantitatif. Penelitian dengan eksperimen merupakan sebuah pendekatan dalam penelitian yang memiliki kekhasan. Kekhasan tersebut bisa dilihat dengan adanya dua hal yakni: pertama, dalam penelitian eksperimen dilakukan pengujian secara langsung pengaruh suatu variabel terhadap variabel lain, yang kedua melakukan pengujian hipotesis hubungan sebab-akibat [10]. Dalam penelitian ini, desain penelitian yang digunakan Quasi Experimental Design. Eksperimen ini dikatakan kuasi, karena dalam praktiknya bukan merupakan eksperimen murni, tetapi seakan-akan murni. Eksperimen ini juga dapat dikatakan sebagai eksperimen semu. Karena beberapa hal, terutama dalam pengontrolan variabelnya, kemungkinan sukar sekali untuk dilakukan eksperimen murni [10]. Pada desain eksperimen ini terdapat kelas yang diperlakukan sebagai eksperimen dan terdapat kelas kontrol sebagai pembanding. Desain kuasi eksperimen yang digunakan dalam penelitian ini adalah Nonequivalent Control Group Design. Desain ini hampir sama dengan pretest-postest control group design, hanya pada desain kegiatan ini antara kelas eksperimen maupun kelas kontrol tidak dipilih secara random [11], hanya kelas dimana peneliti mendapat tugas mengajar. Pada penelitian ini, peneliti memberikan perlakuan menggunakan metode Role Playing dalam pembelajaran Etika Publik pada kelas eksperimen. Sedangkan pada kelas kontrol diberikan perlakuan ceramah. Tahapantahapan perlakuan dalam penelitian ini meliputi pemberian tes awal atau pre test, 
pemberian perlakuan untuk kelas eksperimen dan kontrol, dan tes akhir atau post test.

Subjek penelitian ini adalah peserta pelatihan dasar (latsar) CPNS tahun 2019 pada kelas angkatan 42 dan 81 sebagai kelas eksperimen dan kelas angkatan 68 dan 84 sebagai kelas kontrol. Teknik pengumpulan data yang digunakan dalam penelitian ini adalah mengadakan pre test dan post test pada kelas eksperimen dan kelas kontrol) dan menyebarkan kuesioner pada kelas eksperimen untuk mengukur afektif peserta setelah menerapkan metode pembelajaran. Tes pada dasarnya adalah merupakan suatu alat yang berisi mengenai uraian tugas yang harus dilaksanakan atau soal-soal yang harus dijawab atau diisi oleh peserta didik untuk menilai salah satu aspek perilaku tertentu [12]. Setelah data terkumpul kemudian dilakukan analisis data berupa uji independent sample t-test, uji $n$-gain score dan uji regresi linear sederhana menggunakan bantuan program SPSS for windows 23.

\section{HASIL DAN PEMBAHASAN}

Analisis statistik deskriptif berguna untuk memaparkan dan menggambarkan data penelitian, mencakup jumlah data, nilai maksimal, nilai minimal, nilai rata-rata dan selisih dari hasil nilai sebelum perlakuan dan sesudah perlakuan dalam metode pembelajaran

Tabel 2. Statistik Deskrptif

\begin{tabular}{lcccc}
\hline & $\boldsymbol{N}$ & Min & Max & Mean \\
\hline Pre Test Eksperimen & 60 & 16 & 64 & 44,60 \\
Post Test Eksperimen & 60 & 52 & 96 & 76,93 \\
Pre Test Kontrol & 60 & 12 & 60 & 40,60 \\
Post Test Kontrol & 60 & 40 & 88 & 68,00 \\
Metode Role Playing & 60 & 44 & 92 & 72,27 \\
Valid N (listwise) & 60 & & & \\
\hline
\end{tabular}

Kemudian dilakukan uji independent sample t-test. Uji ini digunakan untuk mengetahui apakah didapati perbedaan rata-rata antara dua sampel yang tidak berpasangan. Dengan hipotesis apakah ada perbedaan antara hasil belajar Etika Publik pada kelas eksperimen dengan kelas kontrol. Dasar pengambilan keputusan uji Independent Sample t-Test: Jika nilai Sig. $(2$-tailed $)<0,05$ maka terdapat perbedaan rata-rata yang signifikan antara hasil belajar pada kelas eksperimen dan kelas kontrol. Jika nilai Sig. (2-tailed) $>0,05$ maka tidak terdapat perbedaan yang signifikan antara hasil belajar pada kelas eksperimen dan kelas kontrol.

Tabel 3. Hasil Uji Independent Sample t-Test

\begin{tabular}{llccr}
\hline & \multicolumn{1}{c}{$\boldsymbol{t}$} & $\boldsymbol{d} \boldsymbol{f}$ & $\begin{array}{c}\text { Sig. (2- } \\
\text { tailed) }\end{array}$ \\
\hline Hasil & $\begin{array}{l}\text { Equal } \\
\text { Belajar }\end{array}$ & 4,171 & 118 &, 000 \\
Etika & $\begin{array}{l}\text { assumed } \\
\text { Publik }\end{array}$ & & & \\
& $\begin{array}{l}\text { Equal } \\
\text { variances } \\
\text { not assumed }\end{array}$ & 4,171 & 117, &, 000 \\
& & 948 & \\
\hline
\end{tabular}

Berdasarkan output test statistik dari hasil uji Independent Sample t-Test tersebut di atas, diperoleh nilai Sig. (2-tailed) sebesar $0,000<0,05$, maka dapat disimpulkan ada perbedaan rata-rata hasil belajar Etika Publik antara kelas kontrol (menggunakan metode ceramah) dengan kelas eksperimen (menggunakan metode role playing). Karena ada perbedaan yang signifikan maka dapat dikatakan bahwa ada pengaruh penggunaan metode belajar role playing terhadap hasil akhir belajar Etika Publik peserta latsar CPNS tahun 2019. Hasil output tersebut sejalan dengan penelitian yang menyatakan bahwa ada perbedaan yang signifikan antara hasil belajar siswa pada kelas eksperimen dan kelas kontrol, hal ini membuktikan bahwa rata-rata nilai siswa pada kelas eksperimen dengan menggunakan metode role playing lebih baik secara signifikan dari pada hasil belajar siswa yang mengikuti pembelajaran dengan metode ceramah [13]. 
Setelah diketahui hasil dari uji independent sample t-test kemudian dilakukan uji Normalized Gain yang bertujuan untuk mengetahui efektivitas penggunaan suatu metode yakni metode role playing dalam penelitian one group pretest posttest design maupun penelitian menggunakan kelompok eksperimen kontrol. Gain score adalah selisih perbedaan antara nilai posttest dan pre-test.

Tabel 4. Hasil Uji N-Gain Score

\begin{tabular}{|c|c|c|c|}
\hline NGain_persen & \multicolumn{2}{|l|}{ Kelas } & \multirow{2}{*}{$\frac{\text { Statistic }}{61.0888}$} \\
\hline \multirow[t]{14}{*}{ NGain_persen } & Eksperimen & Mean & \\
\hline & & Median & 57,1429 \\
\hline & & Std. Deviation & 13,37446 \\
\hline & & Minimum & 42,11 \\
\hline & & Maximum & 88,89 \\
\hline & & Skewness & ,636 \\
\hline & & Kurtosis &,- 620 \\
\hline & Kontrol & Mean & 47,9777 \\
\hline & & Median & 46,6667 \\
\hline & & Std. Deviation & 10,15771 \\
\hline & & Minimum & 28,57 \\
\hline & & Maximum & 70,00 \\
\hline & & Skewness & ,638 \\
\hline & & Kurtosis &,- 397 \\
\hline
\end{tabular}

Berdasarkan hasil penghitungan uji $N$-gain score tersebut, menunjukkan bahwa nilai rata-rata $N$-gain score untuk kelas eksperimen (metode role playing) adalah sebesar 61,0888 atau $61,1 \%$ termasuk dalam kategori cukup efektif. Dengan nilai $N$-gain score minimal $42,1 \%$ dan maksimal $88,89 \%$. Sementara untuk ratarata $N$-gain score untuk kelas kontrol (metode konvensional ceramah) adalah sebesar 47,9777 atau $48,0 \%$ termasuk dalam kategori kurang efektif. Dengan nilai $N$-gain score minimal $28,6 \%$ dan maksimal 70,0\%. Maka dapat disimpulkan bahwa penggunaan metode pembelajaran role playing cukup efektif untuk meningkatkan hasil belajar dalam mata pelatihan etika publik peserta latsar CPNS tahun 2019. Sementara penggunaan metode konvensional ceramah kurang efektif untuk meningkatkan hasil belajar mata pelatihan etika publik peserta latsar CPNS tahun 2019. Hal ini sejalan dengan penelitian yang menyatakan bahwa berdasarkan hasil penelitian didapatkan hasil perhitungan $\mathrm{N}$-Gain Hake data pre test dan post test kelas eksprimen $=0,67$ dengan nilai rata-rata pre test $=30,33$ dan nilai rata-rata post test $=77,34$ sehingga dapat diambil keputusan bahwa metode role playing efektif terhadap hasil akhir pembelajaran dengan $N$-Gain Hake $=0,67$ termasuk ke dalam kategori sedang [14].

Kemudian dilakukan analisis regresi linier sederhana, analisis ini digunakan untuk menguji pengaruh variabel penerapan metode belajar dengan role playing $(X)$ terhadap hasil belajar $(Y)$ peserta latsar CPNS untuk mata pelatihan Etika Publik. Pengambilan keputusan dalam uji regresi linear sederhana dapat mengacu pada dua hal, yakni: Membandingkan nilai signifikansi dengan nilai probabilitas 0,05 : Jika nilai signifikansi $<0,05$, artinya variabel $X$ memberikan pengaruh terhadap variabel $Y$. Jika nilai signifikansi $>0,05$, artinya variabel $X$ tidak memberikan pengaruh terhadap variabel $Y$. Serta membandingkan nilai $t$-hitung dengan $t$ tabel: Jika nilai $t$-hitung $>t$-tabel memiliki arti bahwa variabel $X$ berpengaruh 
terhadap variabel $Y$. Jika nilai $t$-hitung $<t$ memberikan pengaruh terhadap variabel $Y$. tabel memiliki arti bahwa variabel $X$ tidak

Tabel 5. Hasil Uji Regresi Linear Sederhana

\begin{tabular}{lcccc}
\hline Model & $R$ & $R$ Square & Adjusted $R$ Square & Std. Error of the Estimate \\
\hline 1 &, $691^{\mathrm{a}}$ &, 478 &, 469 & 8,461 \\
\hline a. Predictors: & Constant), Metode Role Playing & \\
b. Dependent Variable: Hasil Belajar Etika Publik
\end{tabular}

Tabel di atas menjelaskan besarnya nilai korelasi atau hubungan $(R)$ yaitu sebesar 0,691. Dari output tersebut diperoleh koefisien determinasi ( $R$ Square) sebesar 0,478 , yang memiliki arti bahwa pengaruh variabel bebas yakni metode belajar dengan role playing $(X)$ terhadap variabel terikat yakni hasil belajar mata pelatihan etika publik $(Y)$ adalah sebsar $47,8 \%$. Sisanya sebesar 52,2\% dipengaruhi oleh faktor-faktor selain metode pembelajaran role playing. Hasil ini seirama dengan hasil penelitian yang menyatakan bahwa berdasarkan hasil analisis data diketahui $R$ Square sebesar 0,348 yang berarti bahwa penerapan model role playing mempengaruhi hasil belajar sebesar 34,8\% sedang $65,2 \%$ sisanya dipengaruhi oleh faktor lain di luar penelitian ini [15].

Tabel 6. Persamaan Regresi

\begin{tabular}{llcccc}
\hline Model & \multicolumn{3}{c}{ Unstandardized Coefficients } & $\boldsymbol{t}$ & Sig. \\
& \multicolumn{1}{c}{ Std. Error } \\
\hline 1 & (Constant) & $-2,671$ & 10,987 &,- 243 &, 809 \\
& Metode Role & 1,015 &, 139 & 7,281 &, 000 \\
& Playing & & & & \\
\hline
\end{tabular}

Dari tabel di atas diketahui nilai constant (a) sebesar -2,671, sedang nilai metode role playing (koefisien rgeresi) sebesar 1,015 , sehingga persamaan regresinya dapat ditulis:

$$
\begin{gathered}
Y=a+b X \\
Y=-2,671+1,015 X
\end{gathered}
$$

Persamaan tersebut bisa diartikan bahwa: konstanta sebesar -2,671, memiliki pengertian bahwa nilai konsisten dari variabel hasil belajar adalah sebesar 2,671. Koefisien regresi $X$ sebesar 1,015 menyatakan bahwa setiap penambahan $1 \%$ nilai metode role playing, maka nilai hasil belajar bertambah sebesar 1,015. Koefisen regresi tersebut memiliki nilai positif, maka bisa disimpulkan bahwa arah dari pengaruh variabel $X$ terhadap $Y$ adalah positif. Pengujian hipotesis diketahui nilai t-hitung $=7,281>t$-tabel $=2,002$ dan nilai siginfikansi $0,000<0,05$, maka bisa disimpulkan bahwa variabel metode role playing $(X)$ berpengaruh terhadap hasil belajar mata pelatihan etika publik $(Y)$, yang berarti hipotesis diterima. Hal ini sesuai dengan penelitian yang menyatakan bahwa dari hasil penelitian diperoleh distribusi $t$ yaitu $t$-tabel $=1,67$ sedangkan t-hitung $=12,75$, hal ini berarti bahwa nilai t-hitung berada pada daerah penolakan $\mathrm{H}_{\mathrm{o}}$ sehingga $\mathrm{H}_{1}$ diterima pada taraf signifikan $(\alpha)=0,05$ dan $\mathrm{H}_{\mathrm{o}}$ ditolak [16]. Hal ini berarti metode pembelajaran Role playing pada pokok bahasan hukum Newton memberikan hasil belajar yang lebih tinggi pada siswa kelas $X$.

Bardasarkan pembahasan tersebut di atas menunjukkan bahwa pembelajaran mata pelatihan Etika Publik dengan menerapkan metode role playing bisa berpengaruh secara positif terhadap peningkatan hasil belajar peserta latsar CPNS 2019, sebab dalam proses pembelajarannya, metode 
role playing memberikan suasana yang menyenangkan, sehingga peserta lebih antusias dan berpartisipasi aktif dalam proses pembelajaran di kelas. Bila proses pembelajaran dalam suasana yang menyenangkan, maka pemahaman peserta dalam materi Etika Publik akan meningkat.

\section{SIMPULAN}

Dari hasil data penelitian berdasarkan pengujian statistik yang sudah dilakukan, dapat diambil beberapa simpulan sebagai berikut: (1) Terdapat perbedaan antara nilai rata-rata hasil belajar kelas yang menerapkan metode role playing yakni sebesar 76,93 lebih tinggi 8,93 dibanding nilai rata-rata hasil belajar Etika Publik untuk kelas kontrol dengan menggunakan metode konvensional ceramah sebesar 68,00. Hal ini menunjukkan bahwa penggunaan metode pembelajaran role playing berpengaruh secara signifikan dalam meningkatkan hasil belajar pada mata pelatihan Etika Publik dibanding dengan metode ceramah. (2) Penggunaan metode pembelajaran role playing menghasilkan nilai $N$-gain sebesar $61,1 \%$, hal ini menunjukkan bahwa penggunaan metode role playing cukup efektif untuk meningkatkan hasil belajar Etika Publik. Sementara kelas yang menggunakan metode pembelajaran konvensional ceramah menghasilkan nilai $N$-gain sebesar $48,0 \%$, yang artinya bahwa metode ceramah dinilai kurang efektif untuk meningkatkan hasil belajar mata pelatihan Etika Publik. (3) Penggunaan metode pembelajaran role playing memberikan pengaruh sebesar $47,8 \%$ terhadap hasil belajar mata pelatihan Etika Publik, sedangkan sisanya sebesar 52,2\% dipengaruhi oleh faktor-faktor selain penggunaan metode pembelajaran role playing.

\section{UCAPAN TERIMA KASIH}

Terima kasih saya ucapkan kepada kepala BPSDM Provinsi DKI Jakarta yang telah memberikan kesempatan kepada penulis untuk melakukan improvisasi dalam proses pembelajaran sehingga bisa mewujudkan penelitian ini.

\section{DAFTAR PUSTAKA}

[1] UU No. 5, tentang Aparatur Sipil Negara. Jakarta: Sekretariat Negara RI., 2014.

[2] Peraturan LAN-RI. No. 12, tentang Pelatihan Dasar Calon Pegawai Negeri Sipil (CPNS). Jakarta: Lembaga Administrasi Negara RI., 2018.

[3] S. S. Mukrimah. 53 Metode Belajar dan Pembelajaran. Bandung: Universitas Pendidikan Indonesia, 2014.

[4] H. Subagyo. Role Play untuk Sekolah Menengah Kejuruan Semester 1. Jakarta: Direktorat Pembinaan Sekolah Menengah Kejuruan Kemdikbud RI, 2013.

[5] C. M. S. Sumantri dan D. B. Widjajanti. "Increasing HOTS and Student Belief Towards Mathematics Through Learning with a Role Playing Method". J. Phys. Conf. Ser., vol. 1320, no. 1, hal. 1-7, 2019.

[6] N. N. T. Astrini, M. Sumantri, dan N. W. Rati. "Pengaruh Model Pembelajaran Role Playing Berorientasi Tri Kaya Parisudha terhadap Hasil Belajar IPS Kelas IV". J. Pendidik. IPS Indones., vol. 2, no. 2, hal. 86-95, 2018.

[7] S. Utami, I. Wijianti, dan M. W. Ardhi. "Penerapan Metode Role Playing dengan Media Orkas (Organ Koran Bekas) untuk Meningkatkan Prestasi Belajar Biologi Siswa Kelas XI IPA Madrasah Ma'Arif AlFalah". Florea J. Biol. dan Pembelajarannya, vol. 3, no. 2, hal. 36-44, 2016.

[8] N. Kertia. "Penerapan Model Pembelajaran Kooperatif Tipe Role Playing untuk Meningkatkan Hasil 
Belajar Siswa Kelas X AP1 pada Pelajaran PPKN". J. Pedagog. dan Pembelajaran, vol. 2, no. 1, hal. 2532, 2019.

[9] Dimyati dan Mudjiono. Belajar dan Pembelajaran. Jakarta: Rineka Cipta, 2018.

[10] N. S. Sukmadinata. Metode Penelitian Pendidikan. Bandung: Remaja Rosdakarya, 2010.

[11] Sugiyono. Metode Penelitian Kuantitatif dan Kualitatif dan $R \& D$. Bandung: Alfabeta, 2017.

[12] Z. Arifin. Evaluasi Pembelajaran. Jakarta: Direktorat Jenderal Pendidikan Islam Kementerian Agama RI, 2012.

[13] A. S. Dewi. "Pengaruh Penggunaan Metode Role Playing terhadap Hasil Belajar Siswa Subtema Hebatnya Cita-citaku Kelas IV Sekolah Dasar". J. Persada Kaji. Ilmu Pendidik.
Dasar, vol. 1, no. 1, hal. 36-44, 2017.

[14] N. Ika, M. Husna, D. T. Relita, dan Y. Suriyanti. "Pengaruh Metode Role Playing terhadap Hasil Belajar Kognitif Siswa pada Materi Perkoperasian". SOSIO-DIDAKTIKA Soc. Sci. Educ. J., vol. 6, no. 1, hal. 25-33, 2019.

[15] S. Ariawan. "Countering Zeitgeist of Self-Centered through Role Playing Methods among Junior High School Students". IJECA (International J. Educ. Curric. Appl., vol. 2, no. 3, hal. 44, 2019.

[16] Z. I. Paudi. "Penerapan Metode Role Playing pada Pembelajaran Fisika untuk Meningkatkan Hasil Belajar Siswa". J. Pendidik. Sains Indones. (Indonesian J. Sci. Educ., vol. 7, no. 2, hal. 111-120, 2019. 